\title{
SCANNING ELECTRON MICROSCOPIC OBSERVATION ON THE COCHLEA TREATED WITH FROZEN RESIN CRACKING METHOD TERUYUKI AOKI, M.D.
}

Department of Otolaryngology, Okayama University Medical School. Okayama

(Director: Y. Ogura. M.D.)

By the use of frozen resin cracking method, scanning electron microscopy (SEM) makes it possible to investigate the deeper and finer structures of the inner ear. Another merit of this method is to obtain any sections of the organs without any significant artifactual damages to the tissues.

The inner ears of the guinea pig were fixed and stained with usmic acid. After the cracking procedure frczen specimens were subjected to $\mathrm{CO}_{2}$ critical point drying, the conductive coating of carbon and gold successively, and finally submitted to SEM observation.

Some of the remarkable findings are as follows:

1) The cellular pattern of stria vascularis, spiral prominence and outer sulcus was different each other in the lateral wall of the cochlear duct.

2) A considerably big space was found around nerve fibers within the osseous spiral lamina. Small holes of about $3 \mu$ in diameter were also noted on the lower surface of the osseous spiral lamina. These holes and the space might be intercommunicated between cortilymph and perilymph in the scala tympani.

3) The tectorial membrane seemed to be composed of two layers, namely, the upper fibrous and the lower basal or granular layer. Regarding the relation of the tectorial membrane to hairs of the hair cells, situations were fairly different between outer and inner hair cells. Tips of hairs in the outermost row of outer hair cells penetrated into the granular layer of the membrane making a firm contact. On the other hand, at the lateral side of the outermost row, hairs of the inner hair cells were attached to the tectorial membrane with granular substances protruding from the undersurface of the granular layer.

4) At the hook region, hair cells became less in number mainly at the outermost row closer to the cecum vestibuli.

A $81-0340-23010$

\section{モルモット蝸牛の走査電顕的研究 \\ 一一樹脂泠凍割断法によるー-}

岡山大学医学部耳鼻咽堠科学教室（主任：小會義郎教授)

青 木 輝 行

\section{緒 言}

螖牛膜迷路の形隹学的研究は Alfonso Corti (1851 $)^{11}$

に始まり，その後，光学影微鏡を使用した Hensen
$(1863)^{23}$, Retzius $(1884)^{3)}$, Held $(1926)^{4)}$, Kolmer

$(1927)^{5}$ ，らによりかなり詳細にその構造が解明され

た，近年, Pease \& Baker $(1948)^{6)}$ に上り創始された 
超薄切片法を Engström，5 (1953 $)^{72,3)}$ が内耳膜迷路 の観察に応用し，超薄切片法による透過型電子顕微鏡 （以下，透過電顕）学的研究が始妙られた，以後，多人 の研究者に上り蝸牛膜迷路の内部超微細構造はほとんど 解明され，形態学的研究は完成されたように思われる (Engström $ら^{9,10)}$, Spoendlinn ${ }^{11)}$, Hilding $5^{12)}$, Iurato

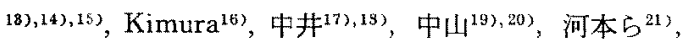
山田 $\left.{ }^{22}\right)$ )。しかし。透過電顕に上る観察方法は内部擭造 の超微細的解明には非常に秀れているが，蛤牛のような 複猚な立体構造を全体的に把握するには困難である，近 年開発された走查型電子顕微鏡（以下，走查電顁）は組 織の表面構造の立体的観察に適しており，耳鼻科領域に 最初に応用したのは, Barber \& Boyde (1968) で家東 などの気管粘膜や嗅部粘膜などを観察し，線毛の立体的 微細構造を研究した。 つづいて Lim \& Lane (1969, $1970)^{24), 25), 26)}$ が走查電影をモルモット蝸牛の観察に応

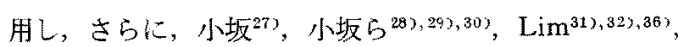
Lindeman $\zeta^{383}$, Engström $5^{34), 35)}$, Marovitz $5^{37), 403}$, 滰口993，など，その報告もしだいに増加し，この間試料 作製法の改良とあいまって，より生体に近い状態での観 察が実用化されてきて種々の新知見が得られてきた。 し かし，従来の走查電顕による報告は組織の表面構造の観 察に限られており，蜩牛の上らな複雑な立体錸造を有す る組織の，特に内部構造の解明には不充分である。今 回，著者は細胞の内部構造を観察する目的で考案された 樹脂冷涷割断法 ${ }^{38}$ )在用いて，モルモット蝡牛を割断し， 表面構造に加えて内部・下部構造までを観察していくつ かの新知見を得たので報告する。

\section{実験材料および実験方法}

\section{A 実験村料}

実験にはプライエル耳介反射鋭敏な，体重300-350gの 有色成熟モルモットを使用した。

\section{B 実験方法}

モルモットを断頭後，すみや加蝸牛骨胞を取り出 し, 骨胞骨壁をできるだけ広範囲に除去し, 蝸牛を露出 させた，ついで，実体顕微鏡下にあぶみ骨，正円空膜を 除去し，蝸牛頂に小孔を開けた。蝸牛組織全体を $2 \%$ 才 スミゥム酸固定液 (0.14M, Veronal buffer $\mathrm{pH} 7.25-$ 7.40）中に浸け，正円空・卵丹空より螎牛頂部に向けて 螖牛組織がすみやかに，かつ充分に固定されるように micropipette 老用いて固定液を版るかか灌流した、ひ きつつ゚き，この固定液中にて1時閣固定後 Veronal buffer にて洗條し，上景エタノール系列に上る脱水を行なっ t.

この間， $20 \%$ タノール中にて試料を小さくし，ゼラ チンカプセル（日本薄局法 No. 2) に螅牛全体が封入で きるようにした，エタノール系列による脱水後，樹脂冷 凍割断法 ${ }^{38}$ を行なった，すなわち，無水アルコール中の 試料を酸化プロピレンに置换し，30分間放置した後，酸 化ブロピレンとセォダイン1500 (Epoxy resin Cemedine Co. Japan）の等量液化移し， $3 \sim 4$ 時閒放置し, つづいてセタダインだけの液中に 24 時間放置した，この 操作により試料中の酸化プロピレンとセメダインが完全 に置換する。試料をセメダインとともにゼラチンカプセ ルに封入し， $-30^{\circ} \mathrm{C}$ 冷凍庫中に $1 \sim 2$ 時間放置し, 試 料を泠涷させた，冷涷庫の中で蝙牛をゼラチンカプセル ごと，ノミ・ツチを使用し，衝慗だけで割断しナイフマ 一クが陚料に加からないよらに注意した。割断された試 料をただちに酸化プロピレンに浸けた。この液を30分ご とに8～10回交換し，試料に浸透したセメダインを除去 し酸化プロピレンに完全に置換させた。この祴料を酷酸 インアミルに置換し, 田中式炭酸ガ 久臨界点乾燥器（鳥 取大・田中敬一教授作製）に上り試料党乾燥させ，日本 電子製試料台に尊電叙料 (Dottite paint D 550) で接着 し、カーボン・金の二重蒸着を行なった，観察には日本 電子製 ISM-U3 型走查型電子顕微鏡を 用 $25 \mathrm{KV}$ 倍率100 30000倍で行なった。また，一部の試料 については，前述のオスミウム酸単独固定を行なったも の党脱水途中の70\%エタノール中にて従来通りの surface preparation technique を用いて標本作製を行な い，90\%エタノール中の試料を液体空素汇浸け,約一 150 ${ }^{\circ} \mathrm{C}$ に念速冷却したものを日本電子盤 Cryoscan にて観 察した。

\section{研究成績}

(1) 螖牛外リン八腔表面

外リン, 腔外側壁は, 鼓室階, 前庭階とむ大差なく, fibrocyte, mesenchymal epithelial cell に似た細胞に被 われているが，上ころところに上皮細胞に被われていな い網目状組織が路出した部位が認められる（図 1，2）。

(2) 蝸牛管内腔外側壁

蜩牛管内腔外側壁には血管条, ラセン隆起，外ラセン

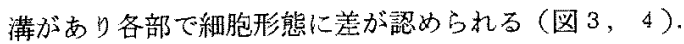
血管条心細胞恃大型のほぼ正六角形をなしている（图4 中のA)．ラセン隆起では，その上粶の細胞は長軸が基 底板と平行な細長い六角形の細胞形態を示し，中央部分 （頂部）で恃血管条上りやや小型の活ぼ正六角形汃らな 
吕細胞形態を示して抢り，更に下縁では，細胞形態はし だいに大きくなり，外ラセン海細胞に移行している(国 4 中のB，C）。そして，以つれれの部位の細胞表面にも 多くの微战毛が諗めら㧈る。

(3) 骨ラセン板

骨ラセン板の割断面を観察すると，骨ラセン板内の神 経線維の周囲にはかなりの広さの間隙があり，骨ラセン 板の下側面に鼓室階已この神経線維周囲腔定結子 $3 \mu$ 内 外の小管腔加認められた（図 5，6，7），骨ラセン板 の鼓室階面は軽石状呈しており大小不同の孔が多数存 在するが、これらの孔はそれぞれが直接骨ラセン板内の 神経線維周困腔と交通しているのではなく，数個の孔が 集まって上述の小管腔となり，この小管腔を介して神経 線維周囲腔上交通している。

(4) コルチトンネル部の基底板

コルチトンネル側のところどころに小孔が認められ (図 8)，一方，鼓室階側には紡鍾形をなした緗胞が蝸牛 軸に平行に数珠つなぎのように配列していて，ところど ころに細胞に被われていない下部の線維楼造の蕗出した 部分が認められる(图9)。しかし、コルチトンネルと 鼓室階を結ぶ管腔は諗められなかった。

(5) 箸膜

蓋膜は大きく2層に分けることができる。

上虽は放射状に走る線維に楅んだ fibrous layer て厚 〈て蓋膜の大部分を占めており，その表面は網目状の covering netで被われている。一方，下層は無满造な 顆粓状物質よりなる薄い granular layer で，ゼラチン 様物質加占構成されているものと想像される。これら2 層の結合は比較的疎であると思われるが，内有毛細胞の 寸ぐ内側 (border cell の直上部付近) で両層が比較的固

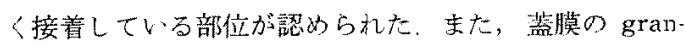
ular layer は内有毛細胞より3個内側の内ラセン满細胞 に付着しており，蓋膜をコルチ器に結びっける錯の役目

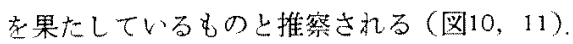

そ心他，granular layer は内一，外有毛細胞䏇毛とも接 着しているが，この点に関しては次項で述心゙る，蕗膜の 外縁部の形態については, fibrous layer $の$ 外縁部は最外 側ダイテルス細胞節板付近で終みているが, granular layer は最外側ダイテルス細胞節板とヘンゼン細胞の境 界部に連続的に付着し，さらにヘンゼン細胞の方に延び てその細胞表面索被っている（因12，13）. Cryoscank 上る観察でも同様に gramular layer が連続していンゼ ン絧胞表面売被って扔り, 試料観察中に乾燥上思われる artifact により granular layer がヘンゼ 細胞より跟 枟してゆく像加認的られた（図14，15）。

(6) 蓋膜と有毛細胞聴毛との関係

外有毛細胞聴毛上蓋膜の関係を胃ると，聼毛はその最 外側列の先端が granular layer にはまり込んだ形で接 着している。德毛先端に granular layer の一部 が剝れて付着している像も認められた（网16，17）。一 方，内有毛細胞聴毛已蓋膜の関係誈 granular layer 加 ら下方に突出した顆粒状物質が㯖毛最外側列の先端外側 面に接着しており，外有毛紏胞聴毛の場合と異なった接 着槏式走示している（図12，18）.

(7) hook 領城の有毛細胞の形態的変化

外有毛細胞山基礶回転では 3 列存在していたものが hook 預域に执いては cecum vestibuli に近づくにつれ て，最外側列の細胞より配列の不整，消失をきたして2 列上なり，やがて第 2 列の細胞毛消失し第1列のみとな り，これ子消失して内有毛細胞列のみ残万が，ついには これも消失している，そして，個々の外有毛細胞聴毛の 配列については，德毛の作るW型の角度は下方に向らに つれてしだいに鈍角となり hook 領域では，ほとんど内 有毛細胞聴毛と同様に一植線となっている(図19，20， 21).

\section{考 按}

走查電㩆観察の試料作製のため，固定，脱水，preparation, 乾燥, 蒸着,など一連の標本処理が必要である が，これらの各段階で起こる試料の artifact をなる心゙く 少なくして，組織の自然の状態を維持する上う試料作製 技術を研究改善することは，特に内耳の上うに微細な形 態学老研究する

教室の滰口 ${ }^{39}$ はこれらの問題につい下比較検討を行 なった。著者も炭酸为不臨界点乾學法を用い乾燥時の artifact 在少なくした。従来上り行なわれてきた surface preparation technique で住試料の表面のみし か観察できず，内部構造，下部楧造を観察するには表面 にある組織索除去する加，試料作製中に偶然生じた割れ 目などを利用する以外こ方法がなく，しか子前者の場合 には artifact が加わり自然の状態を観察することができ ず，後者の場合には偶然性が働き帮際には役立たない。

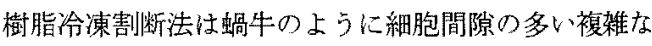
構造を解明するに注極めて有利な方法であり，この方法 によると螖牛を骨ごと割断するので内部の軟組織に対す る artifact 訬なく，得ら机た割断面を钼察寸ることに 上り，表面のみならず螖牛の内部や下部の構造，形態を 
一層明らかにすることができる（図 $5 ， 22 ）$ ，以下，著 者の観察した各部の所睍について考按を行う

(1) 螖牛外リンパ膑内壁面

外リンパの分泌，吸収に関してラセン靸带は重琶なもの の一つと考えられている，すなわち，透過電顕で観察さ れるようにラセン鞄带内には無数の細胞間隙が存在し， その空間は外リンパで满たされている゙1) (Spoendlin, 1963). また, Ilberg (1968) \& thorium dioxide いた夷験で22,43), Tonndorf 5 $5^{442}$ (1962) の生体染色に よる実験でも同様に，鼓室階外リンパに注入されたtrac erがラセン靬带に移行している所見を述心゙ている。 $\operatorname{Lim}^{32)}$ (1972) む走查電顕老用い外りンパ腔内壁老㓋察 し，著者の観察と同様の，ところどころに細胞に被われ ていない下部組織が網目状に露出した所見を述べてい る。この網目状構造物はラセン勒带と思加る。この所 見より，外リンパはこれらの穴を通ってラセン鞋帯内に 入り，周囲に存在する豊富な細動静脈周囲腔を経て吸収 されるものと推察される。

(2) 螖牛管内腔外側壁面

この部は内リンパの分泌，吸収の機能定行なう部位と 従来から述べられている。 今回得られた細胞形態の变化 の所見は， $\operatorname{Lim}^{26)}$ (1970) の走査電影による観察と一致 した。このよらな衈管条，ラセン隆起における緗胞形態 の変化加らもこの部位の内リンパの分泌，吸収に関して 役割に差があることが推察される。

すなわち，血管条とラセン勒帯の関係については， Tonndorf $5^{44}$ は前庭階汃ら蝸牛管へのイオン輸送流 イスネル膜を通してではなく，血管条とラセン物帯を経 由して行なわれると述心，血管条とラセン鞄带の交通を 示晙している. 一方, Masuda 5 (1971) \& Inulin t 用いた tracer 奏験で，これらの交通は発見できなかっ たと述べている，今回の奏験では血管条とラセン鞄带を 結ぶ交通路は発見できなかった。

(3) 骨ラセン板むよび基底板

古くはコルチ器の有毛細胞閒は内リンパに囲立れてい ると想像されていたが． Engström*6)（1960）がラセン 器内腔 (コルチトンネル, 又エル氏腔, 有毛細胞間, outer tunnel) を満たす液体を特にコルチリンパと名付 けた，そしてこの液体は外りンバ，内リンパとは交 通のない特殊なリンパ液と推論した。一方, Smith ${ }^{47}$ （1954）は内耳洨電解睤組成の分析を行ない，外リンパ 恦高 $\mathrm{Na}^{+}$，低 $\mathrm{K}^{+}$，で細胞外液に類似し，内リンパは低 $\mathrm{Na}^{+}$，高 $\mathrm{K}^{+}$，で細胞内液に類似していることをを証明し
た。束た，䉓気生理学的に見るとHodgkin ${ }^{492}$ (1951)は 液体の電解買と細胞膜の関係についての能動榆送説を提 呾した。これによると，神経與奮時にはN沙漠を通し て細胞内に入り，K+は逆に神経内から外に移動すると 述心゙てる。中えに, 内リンパのように低 $\mathrm{Na}^{+}$, 高 $\mathrm{K}^{+}$, の液体のゅでは神経の興雄伝遒は起こり得ないこの意 味からもコルチリンパ内走行する神経の機能が正常に 行なわれるためには，コルチリンパは高 $\mathrm{Na}^{+}$，低 $\mathrm{K}^{+}$, のイオン組成交持つ液体, 寸なわち外りンパに近い性状 在持つ液体でなければならないことになる。そして， Rauch $^{492}$ (1964) はコルチリンパの組成主析しコルチ リンパは外リンバに近いイオン組成を持つが外リンパそ のものではなく, $\mathrm{Na}^{+}, \mathrm{K}^{+}$, のイオン濃度は外リンパに

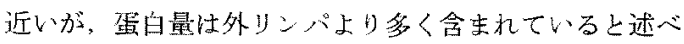
た、しからば、コルチリンパはどこに由来するすのであ 万战。

Schuknecht ${ }^{50)}$ (1963) はネコ蝸牛をアセチルコリン エステラーゼで灌流し，反店が霄ラセン板の特定部分， すな和ち habenula perforata より $0.2 \mathrm{~mm}$ の所にある 小孔からラセン器に向って諗められたことから外りンパ はこの経路を通ってラセン器に進入する上考え Schuknecht channel 乙名付けた. Sando $5^{51)}$ (1971) は干 ルモットの夕モ膜下腔にコロイド状岩素粒子（直径， $200 \sim 500 \AA$ ）を注入し，これが鼓室階に出現し骨ラセン 板下面の小孔在経て骨ラセン板内の神経線維周囲腔に進 人している所兒を述心゙た。しかし， habenula perforata からコルチリンパには准入せず，これは炭素粒子が大 きいためと远べた。

また, Masuda $5^{45)}$ (1971) は Inulin（分子量5000 5500）鼓宝階外リンパに注入したオートラジオグラフ イ一夹験で，Inulinが鼓室階から骨ラセン板下面の小孔 在通り，骨ラセン板内の神経線維周囲腔在経 $て$ habenula perforata に集中し, さらにコルチリンパ内に検出 できた述べている. Duvall ら52)（1972）忙モルモッ トのク七膜下腔に horse radish peroxidase t注入し, 鼓室階在経てコルチりンパ内の細胞に取り込まれている

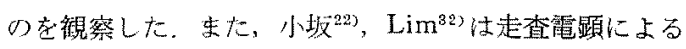
観察を行ない，骨ラセン板の鼓室階面に大小不同の孔を 認め，これが Schuknecht channel であるうと推察し t.

蒂者の樹脂冷凍割断法による骨ラセン板の劃断面の観 察結果から，骨ラセン板の鼓室階面は軽石状芫呈し，小 坂， Lim，の観察した大小不同の孔が存在するが，これ 
らの孔はそれぞれが直接に骨ラセン板内の神経線維周囲 腔と交通しているのではなく，数個の孔が集まって生じ た一個の小管腔を経由して神経線維周囲腔上交通してい た.この所見から，鼓室階外リンパ恃この小孔を介して 神経線維周囲腔に進入しており, さらに神経線維に沿っ $て$ habenula perforata 通過しコルチリンパと交通し ている可能性が考えられる. 従って,この組成は外リン パに近いものと推察される。

鼓室階外リンパとコルチリンパを結ぶ他の経路として は基底板が考元られる.Altmann ら ${ }^{53)}$ (1950) は敘塩 をウサギのクモ膜下腔に注入し，これが鼓室階に出現し 基底板を释てコルチ器に入るのを観察した. Tonndorf $ら^{44)}$, は種々の生体染色法を用いて, 鼓宝階に注入した 染色液が基底板を透過すると述べた。 Ilberg ${ }^{43)}$ (1968)， Ilberg 5 (1969) 注 thorium dioxide が鼓室階か ら基 底板を通ってコルチリンパ隻入するのを観察してい る。野村 ${ }^{55)}$ (1968) も生体染色法を用い鼓室階外リンバ に注入した染色液が基底板を経てダイテルス細胞上ヘン ゼン細胞との間隙を通過するのを観察している。一方， 基底板鼓室階面の上皮について，中山年（1960）は双極 性神経節細胞に似た特異な形態を持ち紡錐形の胞体上, その雨極から出る細長い突起の2 部分から成り, 綝胞の 長軸は基底板の放射状線維上直交する。乙して，この細 胞配列は基底回転では密であるが，上方回転に向5につ れて疎となると述べてい。，小坂 $\left.{ }^{27}\right), \mathrm{Lim}^{32}$ ，む走查電 顕を用いて同様な所見を観察した。

今回の観察に拈ける基底板鼓室階面を被ら紡錐形をな した mesenchymal epithelial cellに似た細胞の数珠状 配列は，各細胞の結合がかなり疎で，上ころどこに細胞 に被われていない下部のセメント様線維構造が露出して 括り，一方，コルチトンネル側の基底板にも大小不同の 小孔が認められ，基底板は比較的蹯な組織構造と考えら れる、Tonndorf ら, Ilberg ら,などの実験をも考えあわ せ,この部を介してのコルチリンパと外リンパの交通の 可能性む推察される。

\section{(4) 堛膜の形態}

蓋漠の形態について Held ${ }^{4}$ (1926) は光学顕微鏡を 用いて上層上り，1) covering net 2) in-between layer 3) fibrcus main layer 4) under border layer 5) homogeneous basal layer $し 5$ 層に分類している. 走查電 顕的観察では，蓋膜は大きく分けて2 層上りなってい る。すなわち，上層は放射状に走る線維に富んだ fibrous layer で厚くて蓋膜の大部分を占め，その上表面は薄い covering net で被われていた。一方，下層は無構造な 顆粒状物質上り成る薄いgranular layer でゼラチン様 物質からなっていると想像される．両層の結合汢比較的 弱く，陚料作製中に分離しや寸いが，内有毛細胞のすぐ 内側 (border cell の直上部付近) で両層が比較的固く 接着している部位が認められた。 $\mathrm{Lim}^{24}$ 注蓋膜裹面の Hensen's stripe の部位に trabecule 样構造物の配列を 認め,これが border cell 付近のコルチ器表面 (inner phalangeal cell $の$ phalanx, または border cell) に接 着し蓋膜をコルチ器に固定するための装置であろうと推 察しているが，著者の観察では内有毛細胞より3個内側

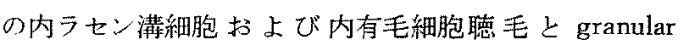
layer が接着している所見を認め, これが蓋膜とコルチ 器を結びつける錪の役目を果たしていると考えられる が, $\operatorname{Lim} の$ 言ら border cell 付近のコルチ器表面との 接着は認められなかった。.以上の所見から，内ラセン湴 紐胞付着部々内有毛細胞聴毛との接着部の閒がHensen's stripe として覾察されるものと推察する.

蓋膜の外縁部の形態については従来，蓋膜の外程はダ イテルス細胞節板に接着している (小坂 ${ }^{273}$ ), 一ンゼン 細胞に接着している (Hilding ${ }^{56}$, Kinura ${ }^{16)}$, Marovitz $5^{37)}$ ，ダイテルス細胞節板およびへンゼン細胞の境界 部に接着している $\left(\mathrm{Lim}^{31)}\right.$, Lindeman $\left.ら^{33)}\right)$,など諸説 があるが，いずれの場合にも蓋膜の外縁部は緎細な線維 状突起の存在のため内リンバが蓋膜下腔（後述）上自由 に交通できると述心ている，たとえば， $\mathrm{Lim}^{311}$ は成熟動 物で法著明ではないが，幻若動物のネコ，リスザルでは 規則的な finger-like process der-like process 形成しているが，モルモットではあ

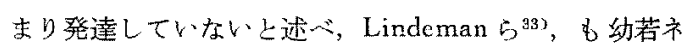
コで蓋膜がダイテルス細胞から剝がされた特に column. like remnant が存在するが, 成熟ネコでは観察できな かった，一方，Tonndorf 543，住生体染色を用いた実

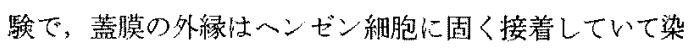
色液が蓋膜の下部のリンパ液中に進入しなかったと述 べ, Rauch 49) (1964) は聴毛の浸っている間隙 (subtectorial space) 恃蓋膜, 内ラセン溝細胞, reticular laminaにより取り囲妄机た一つの閶ざされた腔間を形成 し,ここには内リンパ，コルチリンパと異なった特殊な 液体 (subtectorial lymph) が存在するのではないかと 推察している.今回の観察に括いても fibrous layer の 外縁部洼最外側ダイテルス細胞節板付近で終っている が, granular layer は最外側ダイテルス 細胞節板とへ 
ンゼン細胞の境界部に連続的に接着し，さらにへンゼン 紐胞の方に延びてその細胞表面を被っているなど，蓋膜 下腔がーつの閉鎖腔であることを示㖫する所見が得られ た.ささらに,この点に関して著者は，現在最も artifact の少ない観察方法の一つと言われる Cryoscan に上る観 察で，はじめへンゼン細胞を被っていた granular layer が観察中の beam damage など乾燥による artifact で 路転してゆく像を諗めた。

(5) 蓋膜と聴毛の関係

蓋膜と有毛細胞の形態学的関倸は聴觉機構を解明する うえに, きわ的て重要かつ興味深い課題である。従来, 外有毛細胞聴毛と蓋膜の関倸については，1)全く䧺れ ている，2）単に接触している，3) 接着している，

4) 結合している,などの諸説があった. Kimura ${ }^{163}$ （1966）透過電顕による観察で, 各外有毛細胞聴毛の 最外側列が蓋膜にかなり強く接着しており，その深さは

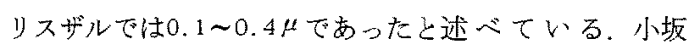
$\zeta^{28)}, \operatorname{Lim}^{317}$ ，滝( ${ }^{39)}$ ，は走查電顕を用いて蓋膜裹面に 最外側列㯖毛の跡と思われる規則正しいW型の小孔配列 を認めている，今回の観察でも，外有毛細胞聴毛はその 最外側列の先端が granular layer に注まり込んで接着 して招り，聴毛先端に granular layer の顆粒状物質が 徳毛のかなり下部の方にまで付着している像が認められ た。このことは両者の接着はある程度強力で，しかも粘 着度を持つものと思われる。

一方，内有毛細胞聴毛之蓋膜の関倸について，Iurato 15) (1967) 沈両者は接着していると述へたが，Kimura ${ }^{16}$ （1966）性内有毛細胞聴毛と蓋膜は接着しないと述心゙， 仮りに接着していたとしても，外有毛細胞聴毛の場合ほ ど強力でないと述べている。これについては, 内有毛細 胞は spiral limbus の比較的硬い tympanic lip の直上 に位置するが，外有毛細胞は機械的刺激を強く受ける基 底板の上に位置するから外有毛細胞聴毛恃蓋膜に一層強 〈接着する必要があるのではないかと推察している。 $\mathrm{Lim}^{31)}$ ，滰口 ${ }^{39)}$ ，も同様に内有毛細胞聴毛上罜膜の接着 は観察できなかった。

今回の観察では，内有毛細胞最外側列聴毛の外側面に 蓋膜の granular layer から下方に哭出した顆粒状物翼 が接着している所見が得られた。このことは蓋膜裹面に 内有毛細胞聴毛の跡上思われる等みが侨められない今 での所見と一致するものと思われ，また，外有毛細胞聴 毛のよらに蓋膜に入り込んで強く接着していないため artifactにより容易に接着が䧺れ，透過電顥に抢いても
今までその接着が認められなかったものと考える。この 上うな蓋膜上内・外有毛細胞聴毛の接着様式の差異が聴 党受容機構に重要な意昧を持つものと推察する。

(6) hook 領城の有毛細胞の形態的変化

その位置的関係から従来の surface preparation technique で潅察され難かったが，樹脂冷湅割断法に上 り，この領域の有毛細胞の形態を観察することができ た。すなかち, 外有毛緗胞は基礎回転では 3 列存在して いたものが hook 領域においては cecum vestibuli に 近づくにつれて外側列よりしだいに消失してゆき，外有 毛細胞聴毛はまったく存在しなくなり。一列の内有毛細 胞聴毛のみとなる。さらに下万に向うにつれて,この内 有毛細胞聴毛さえも消失してゅく形態が明瞭に観察でき た。この hook 領域に扔ける聴毛の消失してゅく状態 は，螖牛頂部にお抽る聴毛の変化を報告した滝口 ${ }^{32)} ， の$ 形態と同様であった。生た，個々の外有毛細胞㯖毛につ いて観察してみると聴毛の作るW型の角度は下方に向う につれてしだいに鈍角となり hook 領域ではほとんど内 有毛細胞㯖毛と同様に一直線となり, 内・外有毛細胞聞 に形態的な差異が認められなくなって行った。

\section{結 語}

樹脂冷凍割断法を応用して作製した試料によりモルモ ッ卜蝸牛を走查電影的纪㘥察して, 以下の所見を得た。

1）外リンパ脫内壁面の構造法, 鼓室階・前庭階とも大 差なく，中胚葉性の細胞に似た細胞化被われていたが， ところどころに細胞が久如し下部組織の露出した部位が 存在した。

2）蝸牛管内腔外側壁では，血管条・ラセン隆起・外ラ セン溝で緗胞形態が変化していた。

3）骨ラセン板下側面に鼓室階と骨ラセン板内の神経線 維淍囲腔を結ぶ直径約 $3 \mu$ 小管腔があり，こ机を介し てコルチリンパと鼓室階外リンパは交通しているものと 推察した.

4）コルチトンネル部の基底板はコルチトンネル側に小 孔の散在を認め, 鼓室階側には細胞の眯な部位が存在し た。これよりコルチトンネル下面でのコルチリンパと鼓 室階外リンパの交通を示唆した。

5）蓋膜の granular layer 注内有毛緗胞より 3 個内側 の内ラセン满細胞, 内有毛細胞聴毛, 外有毛細胞聴毛, ヘンゼン細胞表面と接着していた。外有毛紐胞では各細 胞の最外側列聴毛の 先端が 蓋膜の granular layer には まり込んだ形で接着しているが，内有毛細胞では granular layer から下方に突出した顆粒状物質が最外側列聴 
毛の先端外側面に接着して招り，内・外有毛緇胞聴毛上 觜膜の接着栚式仗異なっていた。

6) hook領域では各有毛細胞聴毛が cecum vestibuli に近つくにつれて最外側列の有毛細胞より，しだいに消 失していた。

\section{付図説明}

図 1 外りンパ腔外侧壁。 fibrocyte, mesenchymal epithelial cell に似た緗胞で被われている。

図 2 图 1 の口部分の应大，上皮䊼胞が久如し網目状の ラセン勒带が露出している.

SL： フセン鞄带 $\times 30000$

図 3 蛤牛管内腔外側壁. $\times 300$

図 4 図3の口部分の桩大. $\times 1000$

A．血管条の細胞は大型のほ注六角形を示している。

B．ラセン隆起上緣の細胞は搰軸が基底板と平行な細 長い六角形索示している。

C、ラセン隆起中央の細胞は，血管条上り小型のほほ 六角形を示している。

図 5 蝸牛第 2 回転割断面.

$\mathrm{ST}$ : 鼓宝階 SM：蝸牛管 SV：前庭階

SG：ラセン神経節 $\times 100$

図6 図5の口部分の拡大，骨ラセン板の下側面に鼓室

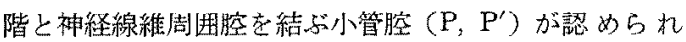

る. ST: 鼓室階 $\mathrm{N}$ ：骨ラセン板内の神経線維 $\times 300$

図 7 図6のP部の桩大. 骨ラセン板鼓室階面の小孔 （知印）の数個吕合流して一つの小管腔上（P）なり神 経線維周囲腔と交通している， 30000

図 8 基底板コルチトンネル側。小孔（矢印）が散在し ている. $N$ : 神経線維 $\times 10000$

图 9 基底板鼓室堦側，紡錐形をなした細胞（C）が蝸 牛軸と平行に数珠つなぎのよ5に配列し，ところどころ に下部の楾維構造が露出している（知印）（×3000

図10 蓋膜の二層構造を示す FL. fibrous layer

GL: granular layer ISC：内ラセン溝稩胞

$\mathrm{OHC}$ : 外有毛細胞 $\mathrm{IHC}$ ：内有毛細胞 $\times 1000$

図11 図100搪大，内有毛細胞の寸ぐ内側で FL と GL が比烄的固人接着している（知印） ×3000

図12 granular layer と聴毛の接着状態および蓄募外縁 部の形態 $\times 3000$

図13 granular layer の顆粒状物筫がへンゼン細胞上ま で延び，その組胞表面老被っている(知印)、×1000 图14Cryoscanで見た蓋膜の形㑷.
TM：蓋膜 $\times 1000$

図15 Cryoscan で観察中に乾燥により蓋膜が墭転しは じわた時の像， $\times 1000$

図16 granular layer 上外有毛細胞の接着状熊.

$\mathrm{GL}$ : granular layer $\mathrm{OHC}$ : 外有毛細胞

1 :第 1 列 2 :第 2 列 $3:$ 第3列 $\times 5000$

图17図160抬大，聴毛の最外側列の先端が granular layerにはまり込んだ形で接着している。また，granular layerの顆粒状物翼が聴毛のかなり下部まで付着してい る (矢印). $\times 20000$

図18図120拉大，granular layer から下方に突出した 顆粒状物缶が内有毛細胞㯖毛最外側列の先端外側面に接 着している（知印）ＧＧ：granular layer

IHC：内有毛細胞 $\times 10000$

图19 Hook 領域の有毛細胞（I）。Cecum vestibuli に 近つくにつれて最外侧外有毛細胞列より配列の不整・消 失をきたして2列となる。

$\mathrm{IHC}$ : 内有毛細胞 $\mathrm{OHC}$ : 外有毛細胞

1 :第1列 2 :第 2 列 3 : 第3列 $\times 3000$

図20 Hook 領域の有毛細胞 (II). 第 2 列の細胞も消失 し第 1 列のみとなる。 $\times 3000$

図21 Hook 領域の有毛細胞 (III)，第 1 列の 細胞当消 失し，やがて内有毛細胞も消失する。 $\times 3000$

図22樹脂冷凍割断法により割断されたコルチ器.

IHC：内有毛細胞 $\mathrm{OHC}$ ：外有毛細胞

HC：ヘンゼン細胞 CT：コルチトンネル

$\mathrm{PC}$ : pillar cell $\times 1000$

\section{文 献}

1) Corti, A.. Recherches sur l'organe de l'ouie des mammifères. Z. wiss. Zool., 3 ; 109-169, 1851.

2) Hensen, V.: Zur Morphologie der Schnecke des Menschen und der Säugetiere. Z. wiss. Zool., 13 ; $481-512,1863$.

3) Retzius, G.: Das Gehörorgan der Wirbeltiere. Samson \& Wallin, Stockholm. 1881.

4) Held, H.: Die Ccchlea der Säuger und der Vögel, ihre Entwicklurg und ihre Bau. Handbuch der Normalen und Patholcgischen Physioligie. (ed. by Bethe, A.) vol. II. 467-526, J. Springer, Berlin. 1926.

5) Kolmer, W.: Gehörorgan. Handbuch der Mikro* skopischen Anatomie des Menschen. (ed. by Möl- 
lendorff, W.) 250-478, Springer, Berlin, 1927.

6) Pease, D.C.\& Baker, R.F.: Sectioning techniques for electron microscopy using a conventional microtome. Prce. Soc. exp. Biol., N.Y., $67 ; 470-474,1948$.

7) Engstrom, H. et al.: Structure of the organ of Corti. I. Outer hair cells. Acta Otolaryngol. 43 ; $1-10,1953$.

8) Engström, H. et al.: Structure of the organ of Corti. II. Supporting structures and their relations to sensory cells and nerve endings. Acta Otolaryngol. $43 ; 323-334,1953$.

9) Engström, H. et al.. Structure and innervation of the sensory hairs of the inner ear. J. Acoust. Soc. Amer.; 9;1356-1363, 1962.

10) Engström. H. et al. Structural pattern of the organ of Corti. Williams \& Wilkins, Co., Baltimore. 1966.

11) Spoendlin, $H$ : The organization of the cochlear receptor. Advances in Oto-Rhino-Laryng., vol. 13, (ed. Karger, S.) Basel. 1966.

12) Hilding, D.A. et al.. Deaf white mink. Electron microscopic study of the inner ear. Ann. Otol. 76 ; $647-663,1967$.

13) Iurato, S.: Submicroscopic structure of the membranous labyrinth. I. The tectorial membrane. $Z$. Zellforsch. $52 ; 105-128,1960$.

14) Iurato, S.: Submicroscopic structure of the membranous labyrinth. II. The epithelium of Corti's organ. Z. Zellforsch. $53 ; 259-298,1961$.

15) Iurato, S.: Submicroscopic structure of the inner ear. Pergamon Press Ltd. Oxford. 1967.

16) Kimura, R.S.: Hairs of the cochlear sensory cells and their attachment to the tectorial membrane. Acta Otolaryngol. 61; 55-72, 1966.

17) Nakai, Y.: An electron microscopic study of the human fetus cochlea. Pract. Oto-Rhino-Laryng. 32 ; $257-267,1970$.

18）中井義明：蛹牛の微組梢造, Audiology. $14 ; 543-$ 565,1971 .

19）中山和彦：電子顕铰鏡による膜迷路の研究。日耳 舜, $63 ; 727-738,1960$.

20) 中山和㢁：聴毛比関する電子影微鏡的観察，Audiology. $12 ; 425-426,1969$.

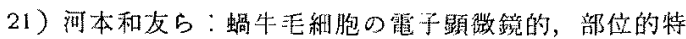
異性。兮鼠と䠦床，16；55-58，1970.

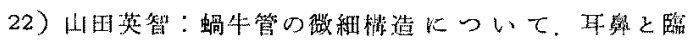
床, $11 ; 209224,1965$.

23) Barber, V.C. et al.: Scanning electron micrescopic studies of cilia. Z. Zellforsch. $84 ; 269-284,1968$.

24) Lim, D.J. et al.: Ccchlear sensory epithelium. A scanning electron microscopic observation. Ann. Otol. $78 ; 827-841,1969$.

25) Lim, D.J. et al.. Vestibular sensory epithelia. Arch. Otolaryngol. 90;283-292, 1969.

26) Lim, D.J. et al.. Three dimensional observation of the inner ear with the scanning electron microscope. Acta Otolaryngol. suppl. 255. 1970.

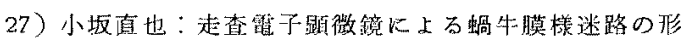

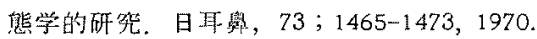

28) Kosaka, N. et al.: Observation on the organ of Corti with scanning electron microscope. Acta Otolaryngol. $72 ; 377-384,1971$.

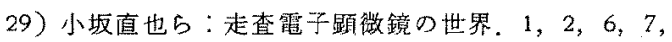
8，9，医学のあゆみ、 $73 ; 5,6,11,12,13,74 ; 1$, 1970.

30）小坂直也5：走查電子㩆镍鏡に上る内耳の钼察。耳 奥之陵床, $17 ; 134-137,1971$.

31) Lim. D.J.: Fine morphology of the tectorial membrane. Its relationship to the organ of Corti. Arch. Otolaryngol. 96; 199-215, 1972.

32) Lim, D.J.: Surface ultrastructure of the cochlear perilymphatic space. J. Laryng. $84 ; 413-428,1970$.

33) Lindeman, H.H. et al.: The sensory hairs and the tectorial membrane in the development of the cat's organ of Corti. Acta Otolaryngol. 72 ; 229-242, 1971.

34) Engström, H.: Inner ear studies. Acta Otolaryngol. suppl. 301. 1972.

35) Engström, H. et al.: Normal structure of the organ of Corti and the effect of noise induced cochlear damage. In sensorineural hearing loss. A Ciba Foundation Symposium. (ed. Walstenholme, G.E.W. and Knight, J.) 127-156, J. \& A. Churchill, London,

36) Lim, D.J.: Acoustic damage of the cochlea. A scanning and transmission electron microscopic 
observation. Arch. Otolaryngol. 94 ; 294-305, 1971.

37) Marovitz, W.F. et al.: Specialized extracellular structures of the inner ear. Scanning electron microscope. /IITRI/ 313-320, 1971.

38) Tanaka, K.: Frozed resin cracking method for scanning electron microscopy of biological materials. Die Naturewissenschaften. $59 ; 77,1972$.

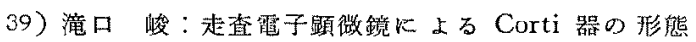
学的研究。日耳奥, 76;578-585, 1973.

40) Marovitz. W.F. et al.: Evaluation of preparative techniques for the scanning electron microscope. Laryngoscope. $80 ; 1680-1790,1970$.

41) Spoendlin, H.H. et al.: Histochemical localization of dehydrogenases in the cochlea of living animals. Laryngoscope. 73 ; 1061-1083, 1963.

42) Ilberg, C.V.: Elektronen Mikroskopische Untersuchung über Diffusion und Resorption von Thoriumdioxyd an der Meerschweinchenschnecke. Reissnersche Membran. Archiv kli. exper. Ohren-Nasenund Kehlkopfheilk. 190 ; 426-436, 1968.

43) llberg, C.V.: Elektronen Mikroskopische Untersuchung über Diffusion und Resorption von Thoriumdioxyd an der Meerschweinchenschnecke. Ligamentum spirale und Stria vascularis. Archiv kli. exper. Ohren-Nasen- und Kehlkopfheilk. $190 ; 415-$ $425,1968$.

44) Tonndorf, J. et al.: Permeability of intracochlear membranes to various vital stains. Ann. Otol. 71 ; 801-841, 1962.

45) Masuda, Y.et al.. Perilymphatic communication routes in guinea pig cochlea. Arch. Otolaryngol. $94 ; 240-245,1971$.

46) Engström, H.: The Cortilymph, the third lymph of the inner ear, Acta Morph. Neerl. Scand. 3; 195-204, 1960.

47) Smith, C.A. et al.: The electrolytes of the labyrinthine fluids. Laryngoscope, 64;141-153, 1954.
48) Hodgkin, A.L.: The ionic basis of electrical activity in nerve and muscle. Biol. Rev. 26 ; 339409, 1951.

49) Rauch, S.: Biochemie des Hörorgans. Georg Thieme. Stuttgart. 1964.

50) Schuknecht, H.F. et al.: Experimental observations on the fluid physiology of the inner ear. Ann. Otol. $72 ; 687-712,1963$.

51) Sando, 1. et al.: Perilymphatic communication routes in guinea pig cochlea. Ann. Otol. $80 ; 826-$ $834,1971$.

52) Duvall, A.J. et al.: Cochlear transport of horse radisch peroxidase. Ann. Otol. 81 ; 705-713, 1972.

53) Altmann, $F$, et al.: New investigations on the physiology of the labyrinthine fluids. Laryngoscope $60 ; 727-739,1950$.

54) Ilberg, C.V. et al.: Permeability of the inner ear membranes. Acta Otolaryngol. $67 ; 165-170,1969$.

55）野村菒也：コルチリンバ一外リンパ腔との関倸に ついて一, 耳鼻臨, 61；4. 55-58, 1968.

56) Hilding, A.C.: Studies on the otic labyrinth. II. A theory on the stimulation of the organ of Corti by sound vibrations. Ann. Otol. $61 ; 371-383,1952$.

稿を終るに臨子, 御指導, 御校閲を睗った恩師小倉義 郎教授に深甚の謝意を表します。

また。御丁㲰な御助言。御協力を頂いた，田中徽博

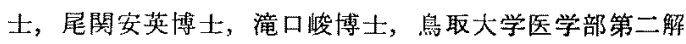
剖学教室田中敌一数授, 倉レ中央研究所窪津彰氏に媣く 感謝しますと共に, 松原浄先生をはじめ教室員諸兄に心 より御礼中し上げます。

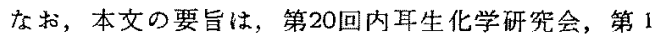
回日本耳科学会総会にて発表した。

(原稿受付昭和52.12.12日)

別刷請求先 同山市鹿田町2-5-1 岡山大学医学部 耳聯咽喉科学教室 青木 煇行 
青木論文付図 (1)

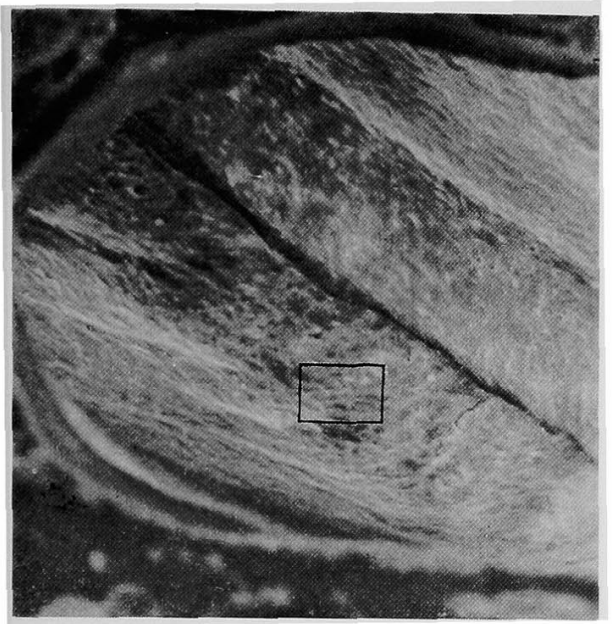

図 1

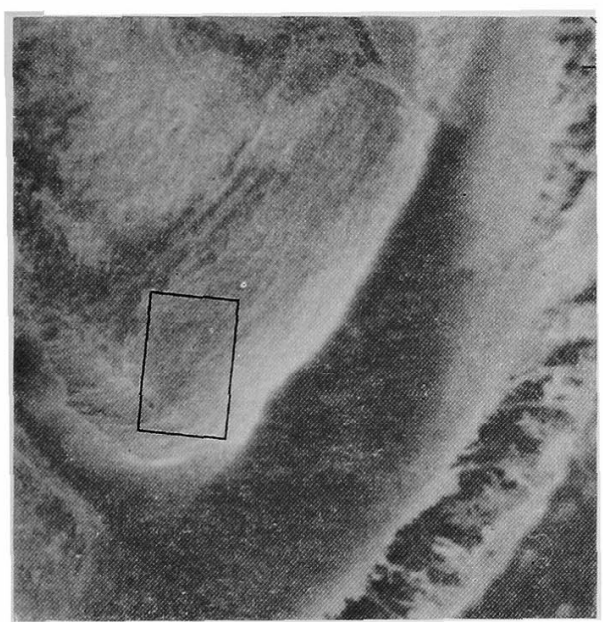

図 3

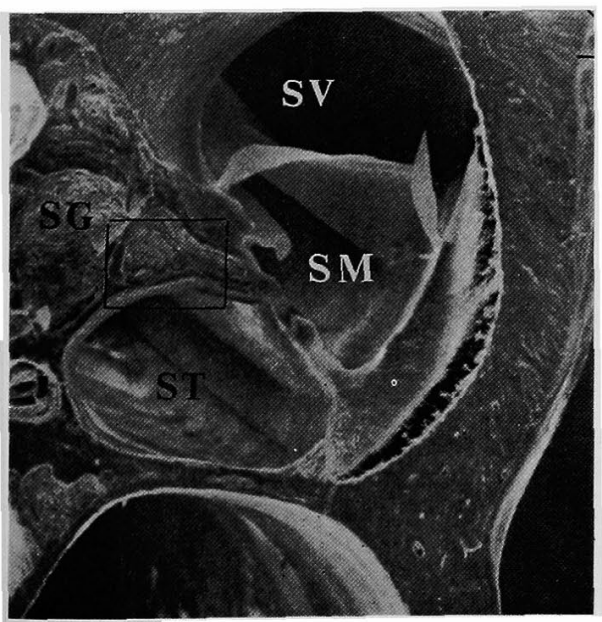

図 5

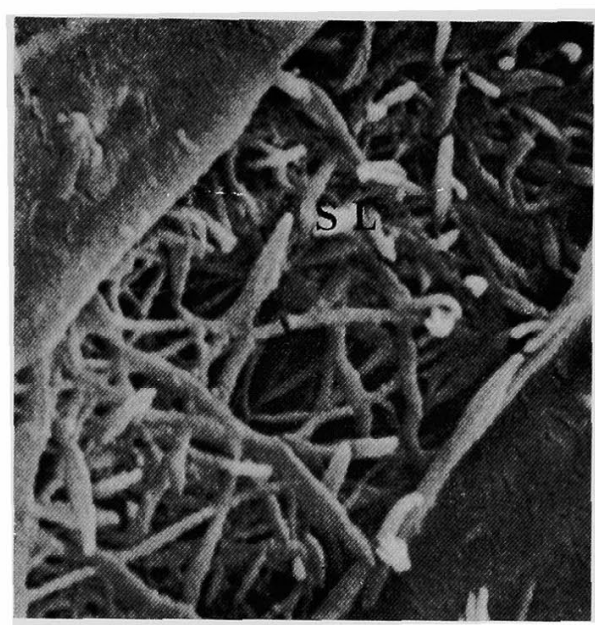

図 2

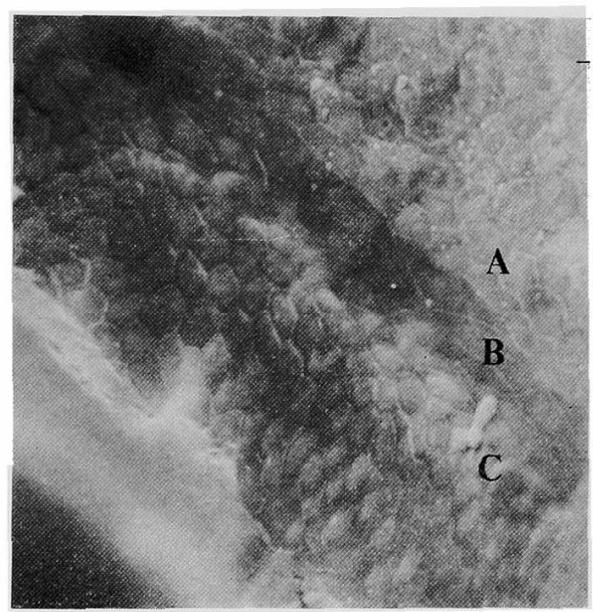

図 4

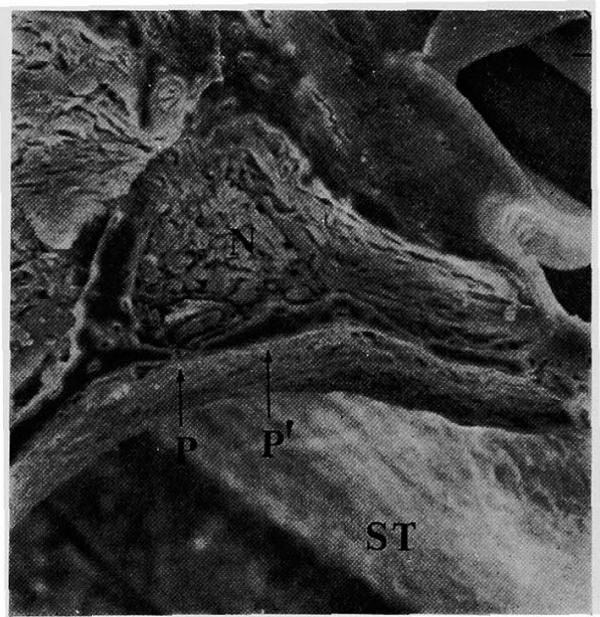

図 6 
青木論文付図 (2)

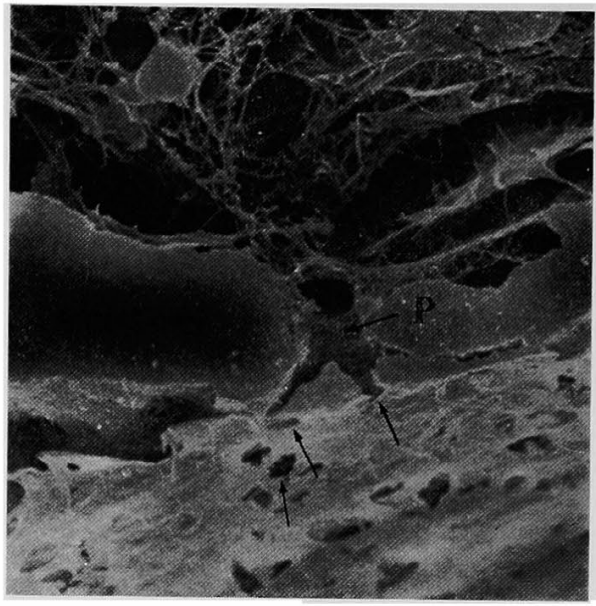

図 7

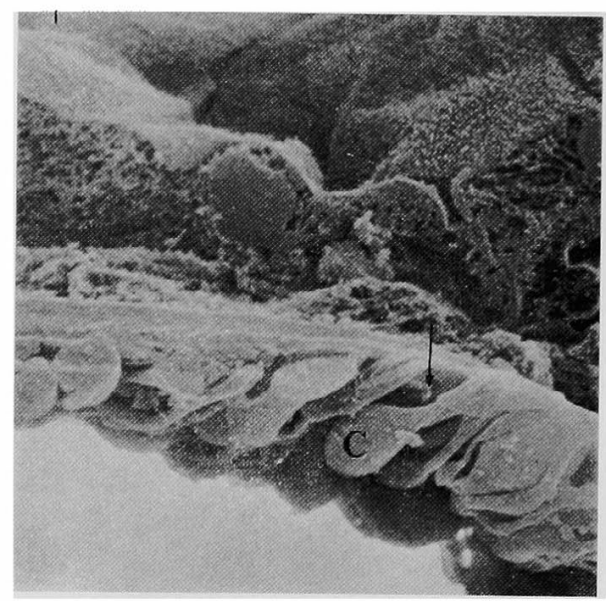

図 9

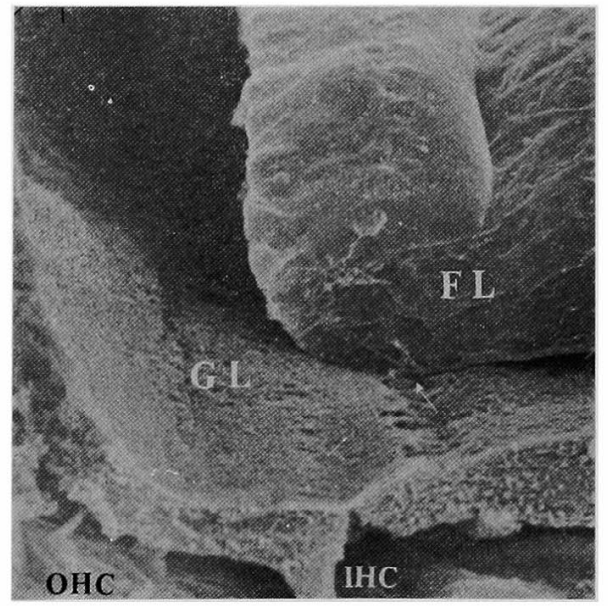

図 11

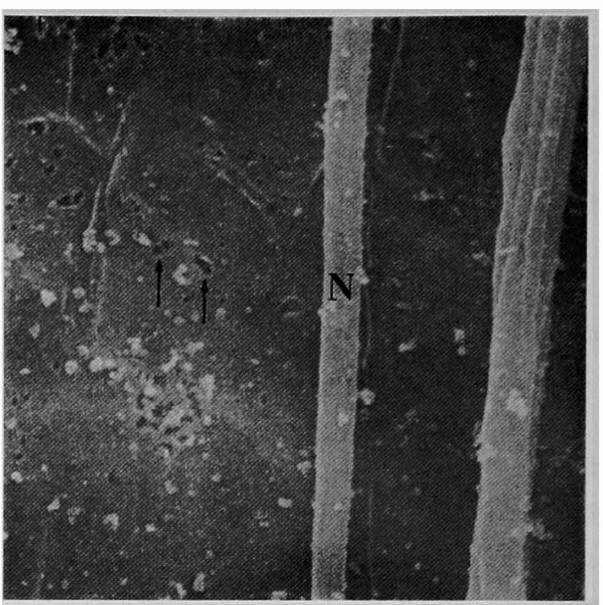

図 8

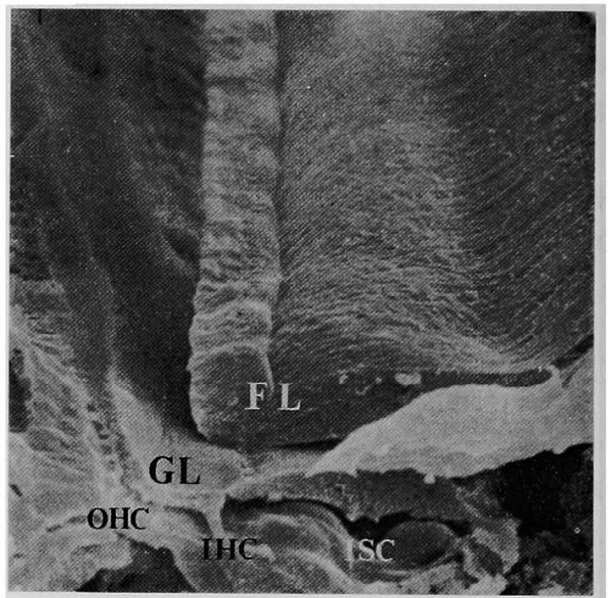

図 10

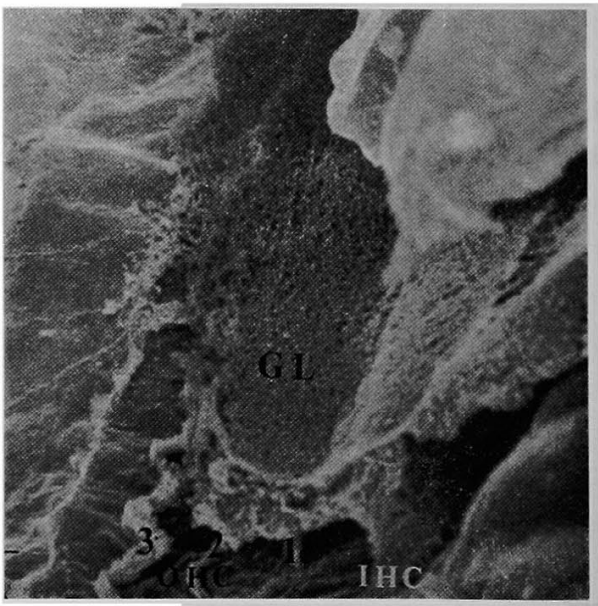

図 12 
青木論文付図 (3)

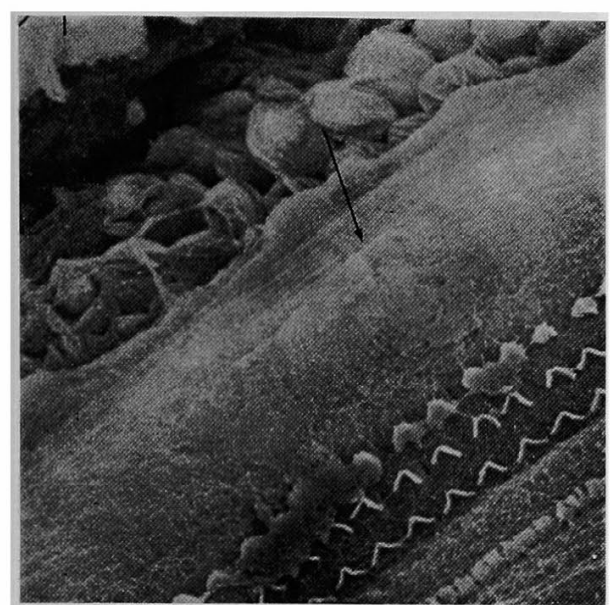

図 13

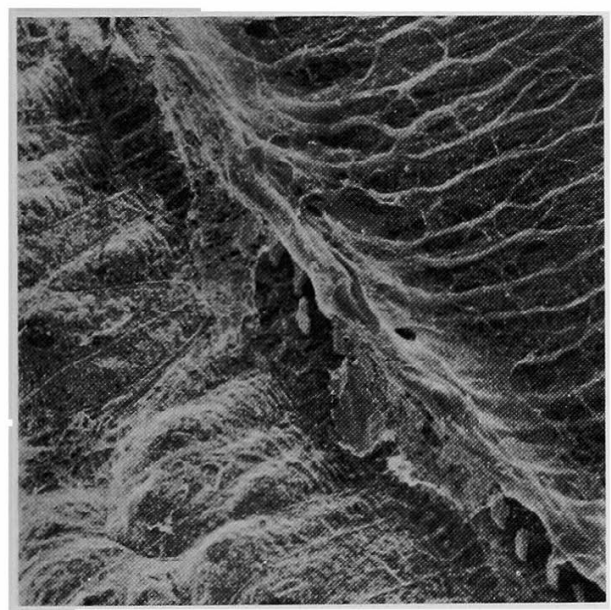

図 15

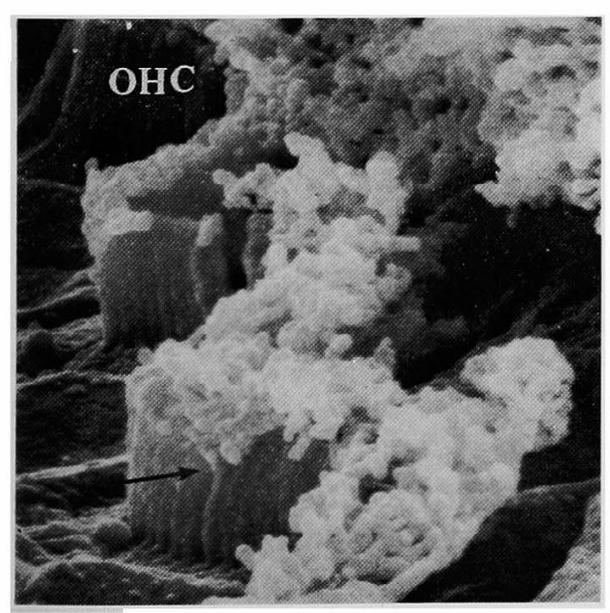

图 17

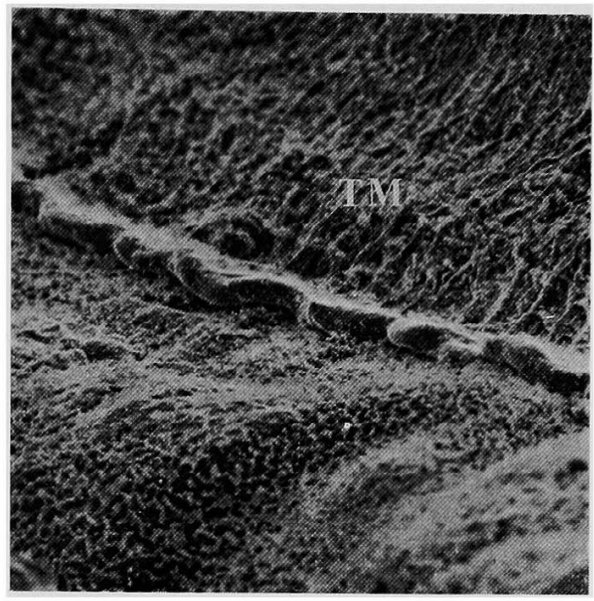

図 14

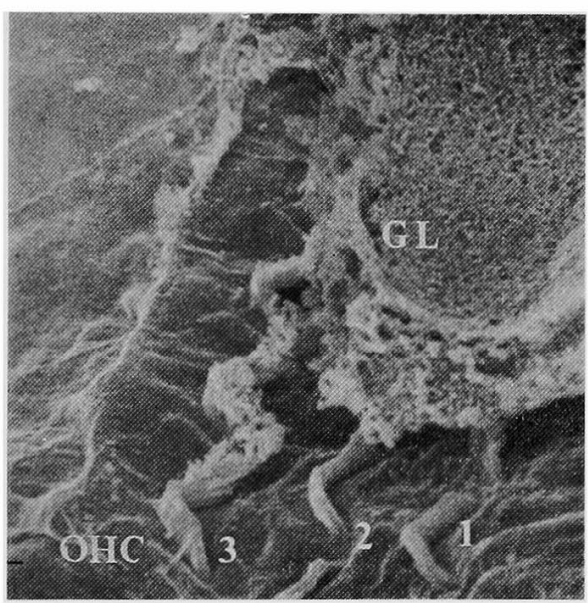

図 16

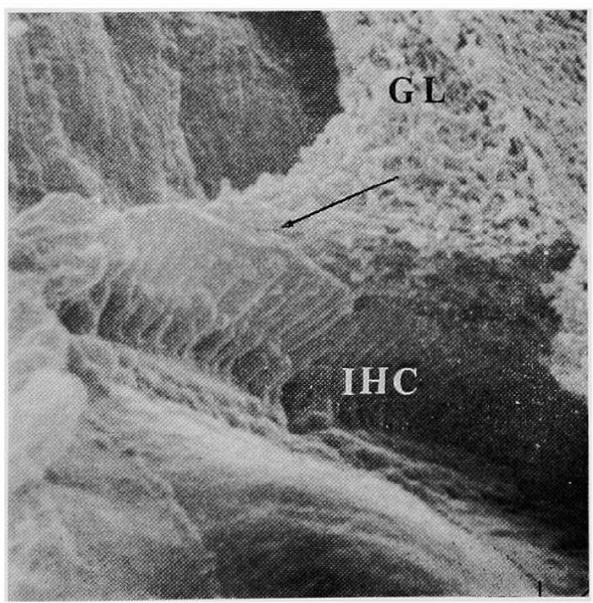

図 18 
青木論文付図(4)

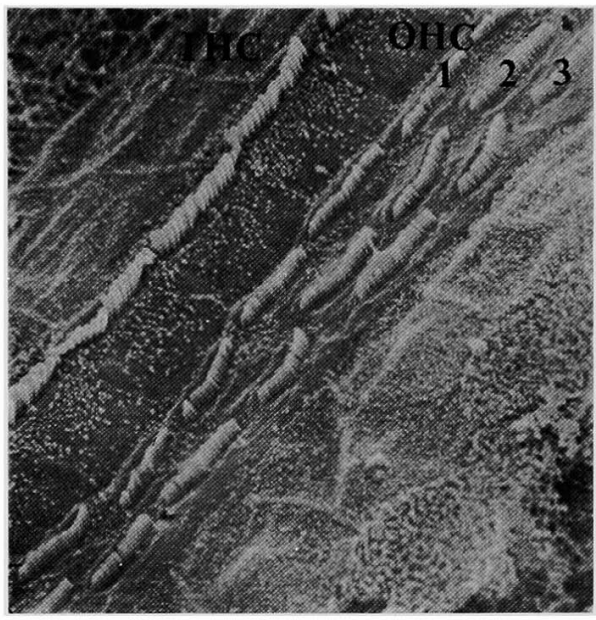

図 19

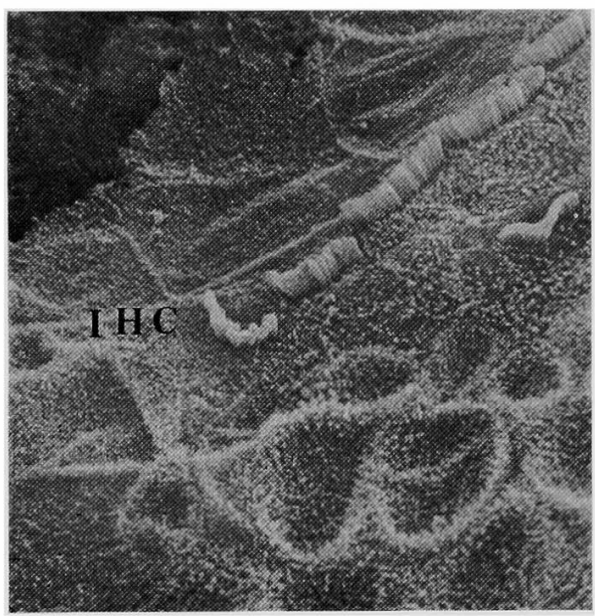

图 21

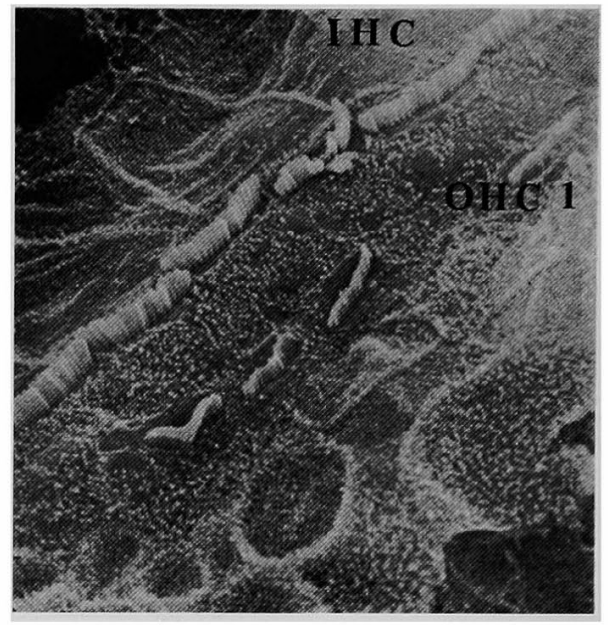

図 20

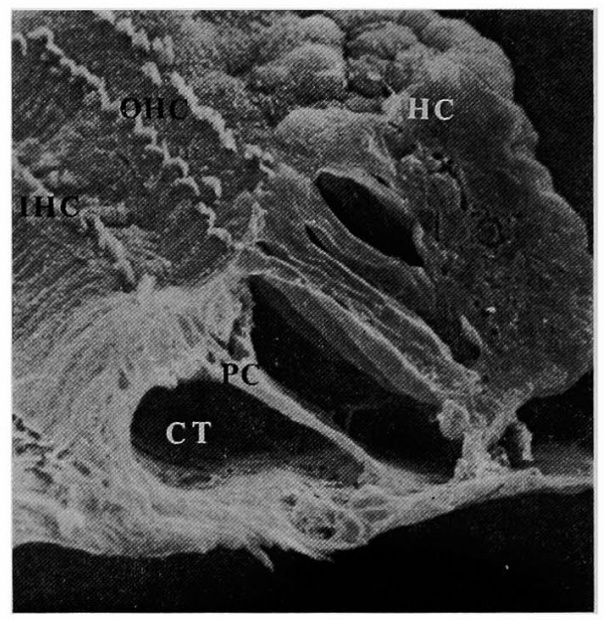

図 22 